\title{
An Analysis on 2015 Village-Based English Training Program of Banyuwangi Regency
}

Zesy Irama

English Educational Departement, Universitas PGRI Banyuwangi

\author{
Received : Monday, October 9, 2017 \\ Revised : Wednesday, October 11,2017 \\ Accepted : Wednesday, October 25, 2017
}

\section{Abstract}

Tourism is an important economic sector in Indonesia. Natural and cultural resources are important components of tourism in Indonesia. Banyuwangi is one of the regencies in East Java which is located on the eastern point of Java. This is the largest regency of Java island with total area reaching

$5782.50 \mathrm{~km} 2$. It attracts tourists to come. Among the factors the charm of its nature and culture.

The rich of natural and cultural resources encourages local government to more aggressively promote Banyuwangi as regency eligible to be one of favorite Indonesia tourism destinations. Banyuwangi government has continually promoted the tourism objects and attractions through Department of Culture and Tourism.

The study is aimed to examine the implementation of the program. To know the strengths, weaknesses, opportunities and threats of the program. This research used descriptive qualitative method. It involves organizing, accounting for and explaining the data (Cohen et al, 2007: 461). Data collection method in this study include observation, interviews, and documentation. The data were analyzed by using SWOT analysis. SWOT analysis is used to formulate the recommendations in order to produce a model or right strategy for village-based English training.

The result of the research have eleven supporting factors and have eight obstacle factors of English training program. In the Tamansari and Bangsring.

\section{Keywords:Village-Based; Village Based English Training}

\section{A. Introduction}

English is the language most commonly used throughout the world. English is the third native language most widely spoken in the world, after Mandarin Chinese and Spanish. English is also used as a second language and the official language by the European Union, the Commonwealth, and the United Nations, as well as a variety of other organizations. In addition, the extent of the use of English is also used by spread of US culture and technology that predominates throughout the 20th century. These things have led to the current English is the main 
language and an unofficial (de facto) is regarded as the lingua franca in many parts of the world.

Undoubtedly, tourism information service will use at least one foreign language. English as a language that widely used to communicate by people across cultures becoming the reason for the tourism practitioners to master this language. From this description, it can be stated that the successful management of this tourism potential is determined by human resources insight to the world of tourism, and the provision of satisfactory information about Banyuwangi tourism attraction in English.

To lead from background already mentioned above, the researcher examined the English language training program in 2015 and took the title An Analysis On 2015 Village-Based English Training Program of Banyuwangi Regency.

\section{Statement of the problem}

Based on the background, the problems of the research are devided into two:

a. General problem

"How is the implementation of village-based English training program of Banyuwangi Regency in 2015?"

b. Specific problem

1) How are the strengths of 2015 Village-Based English Training Program?

2) How are the weaknesses of 2015 Village-Based English Training Program?

3) How are the opportunities of 2015 Village-Based English Training Program?

4) How are the threats of 2015 Village-Based English Training Program?

\section{Objective of the study}

The objective of the study is divided into two:

a. The general objective of this research is to examine the implementation of 2015 Village-Based English Training Program.

b. The specific of objective can be described as follows

1) To know the strengths of 2015 Village-Based English Training Program.

2) To know the weaknesses of 2015 Village-Based English Training Program.

3) To know the opportunities of 2015 Village-Based English Training Program.

4) To know the threats of 2015 Village-Based English Training program

\section{Limitation of Key Terms}

The main topic of this research is the implementation of 2015 Village- Based English Training Program of Banyuwangi. The analysis focused on the implementation of the program 


\section{Definition of Key Terms}

Based on the exposure from the background of the problem, the researcher determined some of the key terms of the study

a. Village based

Analysis is the process of breaking a complex topic or substance into smaller parts in order to gain a better understanding of it

b. English training program

English training program is one of the programs of the Government of Banyuwangi in 2015 that serves to provide the facilities and benefits of personal skills (skills to communicate using the English language) for the villagers. And to improve the ability of people or job seekers in the English language and improve human resources.

\section{B. Research Method}

\section{Research Design}

This research used descriptive qualitative method. It involves organizing, accounting for and explaining the data (Cohen et al, 2007: 461). It means that the data collected are not in the form of numbers, but the data will be obtained from interview. The data were analyzed qualitatively because the characteristic of the data used is non-numerical data. The qualitative research concerned with qualitative phenomenon, or more specially, the aspects relating to or involving quality or kind (Khotari, 2004: 3). The result of this study is descriptive data and it will be presented in the form of words.

\section{Determining the location of the research}

The Location research was determined by using purposive method.they are Tamansari in Licin District, Kampunganyar and Kemiren in Glagah District, and bangsringg in Wongsorejo District. The research was conducted in four villages for the consideration of each village has the advantages of sites situated in the territory of the village itself and adjacent to the village.

\section{Data collecting method}

Data collection method in this study include observation, interviews, and documentation. As for ways of collecting data can be itemized as follows: ( 1 ) Observation, which is one way to put researchers to see and find out if the trainees are directly involved in tourism management in the region. ( 2 ) Interview, that is one way to put researcher to uncover how the research subjects give meaning to the English training program in their region. ( 3 ) Documentation, that is one way to put researcher to determine how the process from start until the final achievement village-based English training program which are in the four research sites

\section{Data sources}

This research used descriptive qualitative method. The data gathered were classified into: 
a. Primary data

The primary data obtained directly from the research that is by doing interviews, observation and participant observation. These data from the document copies of material during the training as well as documents from the participants of the program. Documents were also obtained from the trainers.Researchers use this data to find out information directly on village-based English training program in the Licin, Kampunganyar, Kemiren and Bangsring.

To get information from primary data sources, especially the master problem of village based English training program, it is necessary to informants

who really know the issue in depht. Determination of informants or subjects of this study using purposive sampling technique is to choose people who know clearly about 2015 village-based English training program

b. Secondary data

The secondary data obtained from literature sources and other sources such as official documents of government agencies, newspaper and so on. Secondary data is then used by researchers to strenghten and supplement the results of the discovery of information on primary data.

\section{Data analysis method}

Data were collected through observation, interviews, and documentation in the form of qualitative data. The technique used to analyze the research data is descriptive interpretative analysis techniques with the following steps: 1) select the document/data that is relevant, 2) make a record of objective, 3) concluded the data by creating a format based on the desired data analysis techniques researchers.

The data were analyzed by using SWOT analysis. Miles and Huberman (1984) in Sugiyono (2013 : 246) statement that the activity in the analysis of qualitative data is data reduction, data display and conclusion drawing/verification.

Below is a picture that shows interactive cycle precesses are interlinked and continued throughout the study.

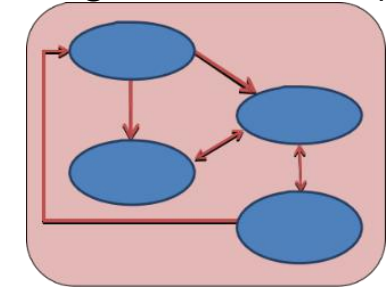

SWOT analysis is used to formulate the recommendations in order to produce a model or right strategy for village-based English training. SWOT analysis is identification of factors systematically to formulate strategy. This analysis is based on logic to maximize the strengths and opportunities, but simultaneously to minimize the 
weaknesses and threats. Strategic decision making process is always associated with the development of the missions, purposes, strategies, and wisdom (Rangkuti, 2003).

By searching for factors weaknesses, opportunities and threats from research location then analyzed in such a way that the results described in the descriptive and is used to determine the steps as well as village- based English training model on a research

\section{The Research Procedure}

In conducting this research, some procedures were taken in doing the research. Those steps are as follows:

1) 1)Determining the data source (documents that will be examined).

2) 2)Establishing the problems and the objectives of the research.

3) 3)Identifying the strengths, weaknesses, opportunities, and threats of the training program.

4) Concluding the research and giving suggestion related to the result of this research

\section{General Discussion}

Village-based English training program is one of the programs of the Government of Banyuwangi in 2015 that serves to provide the facilities and benefits of personal skills (skills to communicate using the English language) for the villagers. The village-based English training program is to improve the ability of people or job seekers in the English language and improve human resources in Banyuwangi and to welcome the integration of people between countries, especially in the ASEAN Economic Community. It is also to prepare Banyuwangi tourism development which grows rapidly. English training program targets are the productive ages range between of 18-40 years old, living in the village areas Banyuwangi and yet have the ability to speak English well.

Village-based English training program involving crosssectoral the Department of Education, Department of Youth and Sports, Department of Social Services, Department of Manpower and Transmigration, The Association of Training Providers and Courses of Indonesia and Association of Overseers Indonesia. Department of Education handles the academic aspect in the form of modules and the technical instructions assisted by the Association of Training Providers and Courses of Indonesia. Department of Youth and Sports has synergy with Department of Education on duty to identify and recruite candidates, form groups consisting of 12 people to become trainees, and recruit trainers. Department of Manpower and Transmigration distributed the program participated in the program.

English language training program is organized by nonformal educational institutions. Desy Education which is located on the Jl. Hayam Wuruk No. 75-77. This program run from May to July in 2015. The organizers implementing learning programs as much as 201 hours of lessons with 67 times face to face, each face 
3 hours of lesson, time each 60 minutes. Supporting English training program includes: a) a forum of regional leaders, b) the local work unit, c) subdistrict leadership forum along with the village officials or in each area of the program.

Trainers English training must meet several criteria, including: a) have the competence to speak English, b) have academic qualifications S1 / D4 or has a certificate English training, c) or under certain conditions Field Work Experience students can be included to support village-based English training in Banyuwangi regency.

The material taught is focused on improving speaking skills, writing skills, and listening skills. At the time of the training, at the tim of the training, trainees immediately practice with fellow trainees. After three months of training, the trainees take final exams of regency level and national level. On October 19, 2015, Department of Education held a regency level examinations held at GOR Tawangalun. Meanwhile, on 8 November 2015 the Department of Education and Certification of Competency as well as the Ministries of Education and Culture hold a national competency test in SMK Banyuwang.

Budget of a village-based English training program about 1 billion rupiah. English training funding sourced from: a) the budget revenue and expenditure, b) budget revenues and expenditures of the provinces, c) the revenue and expenditure budget Banyuwangi Regency, d) sourced from a third party which is not binding.

The trainee in the national competency exam as many as 321 trainees best taken at the regency-level exam conducted. From all the trainee who took the exam, $80 \%$ of them had mastered the English well. The indicator, from the 16 trainees who were tested by the chairman Certification of Competency to the base material speaking ability, as many as 12 peoples have advanced to communicate fluently.

\section{The Implementation}

Village -based English training program was conducted in 217 villages across the Banyuwangi regency in 2015. The training was attended by 2,064 trainees from various backgrounds. Throughout there are 205 groups English training program in Banyuwangi regency. The researcher used four sample villages as a measure of success of the program, namely: Tamansari village is located in Licin, Kampunganyar Village and Kemiren Village is located in the Glagah District, as well as the Bangsring village is located in the Wongsorejo District.

\section{Internal Factors}

In the internal factors there are two important factors that influence, namely the factor related to stength and the factors related with weaknes.

First, The strength factors. Village-based English training program have been studied to work as a strength 
a. Village based English training program is free

The allocation of funds spent by the Government of Banyuwangi for this program is quite large, about 1 billion rupiah. The funding comes from several budget, including; a) the budget revenue and expenditure, b) budget revenues and expenditures of the provinces, c) the revenue and expenditure budget Banyuwangi Regency, d) sourced from a third party which is not binding.

b. The trainee from villagers around tourist attraction.

As one way of improving the quality of human resources, this training is successful if the trainees in the training were the local peoples of the village. They live around place tourism spot sites in their area

c. The hall of village office as a venue for training.

One of support by the village government in this program is allow the trainees to use the hall of village office as a venue for training activities. From the four research locations, three of which use the hall of village office as a venue of English training program. Except Bangsring that use Bunder Beach as a training venue

d. An enthusiastic training in two villages is high.

At two research locations, namely Tamansari and Bangsring, the trainee who attend training amount exceeds the quota set by the government. The number of trainees from Tamansari are 15 trainee whereas much of Bangsing 25 trainees. The quota set by the government as many as 12 trainees per group. With the number of trainees exceeds the quota limit, it could be interpreted the villagers in the two village started to realize the importance of English

e. Trainers are competence.

The government of Banyuwangi Regency has set criteria for trainers who will teach in the English training program. Some of the criteria who will become trainers include have the competence to speak English and have academic qualifications S1 / D4 or has a certificate English training. All the criteria set by the government of Banyuwangi has been owned by the trainers who teach at four study sites

f. Each village has a leading tourist attraction.

From the four villages that used the study site, all villages have respective advantages in the field of tourism. This is a distinct advantage because it can be used as a distribution of labor for trainees who have English training. They could choose from a variety of fields among others become a local guide or become a tour leader in tourism in their areas.

Second, the factors of weaknesses. Besides having the strength factors, village-based English training program also has its weaknesses. 
C. Conclusion

After conducting a research, making conclusion and suggestion are the final parts in which the findings of the research are summarized according to the problems of the research. Having conducted the analysis of the village-based English training program, the conclusion and suggestion from this research can finally be drawn as follow:

1) Village-based English training involves many stakeholders from service government.

2) There are eleven supporting factors as follows; (1) Village-based English training program is free. (2) The trainee from villagers around tourist attraction. (3) The hall of village ofice as a venue for training. (4) An enthusiastic training in two villages is high. (5) Trainers are competence. (6) Each village has a leading tourist attraction. (7) Village-based English training program is sustainable. (8) Employment opportunities into local guide. (9) Location of three villages are close together and have their respective tourism excellence. (10) The presence of third party that helps the development of tourism in Tamansari.(11) Three events program Banyuwangi Festival in the village of Kemiren.

3) There are eight obstacle factors of English training program as follows; (1) In Tamnansari meeting only once in a week. (2) The trainee from Kampunganyar is village officer. (3) Interests of participants in Kemiren very low. (4) The trainees from Bangsring only from one hamlet. (5) The number of trainees who took the final exam very minimal. (6) The number of trainees who became tourism players are very minimal. (7) Nothing distriburion of labor by Department of Manpower and Transmigration. (8) The trainees have difficulty in making a license as a professional guide

\section{Acknowledgement}

First and foremost, heartfelt gratitude and thankfulness is due to the Merciful Allah Subhanahu wata'ala. Everything, I have done will be nothing without Allah's bless. The best gratitude is our prophet Muhammad SAW for His Syafa' at.

During writing this thesis, they are a lot of people who give great helps from the beginning phase if the research until finished. I would like to express my thanks to:

1) 1)Drs. H. Teguh Sumarno, MM, as The Rector of PGRI University of Banyuwangi.

2) 2)Drs. Sunari, as the Headmaster of Departmen of Educational Banyuwangi.

3) 3)Abdul Munir, M.Pd, as The Dean of Language and Art Faculty who has given me spirit to finishing this thesis.

4) 4)Wulan Wangi, M.Pd, as The Head of English Educational Department and as The First Consultant who has always given me support, valuable comment, correction and suggestion in writing and finishing this thesis. 
5) Wiwin Indiarti, S.S., M.Hum., as The Second Consultant who has always given me support, valuable comment, correction and suggestion in writing and finishing this thesis.

Finally, the researcher greatly hopes that thesis will be useful for the reader someone else who reads and thanks a lot for all your helps. Insha Allah God Bless you all, Amin

\section{E. Reference}

Cohen, Louis et al. 2007. Research Methods in Education (sixth edition). New York: Routledge.

Gatehouse, K., 2001. "Key Issues in English for Specific Purposes (ESP) Curriculum Development", The Internet TESL Journal, 7(10), Retrieved http://iteslj.org/Articles/Gatehouse_ESP.html

Jumlah Pulau di Indonesia 'Berkurang' 4.042 Buah. Metrotvnews. Friday, October 18, 2013. Accessed on October 20, 2013.

Kennedy, C. \& Bolitho, R. (1984) English for Specific Purposes. London: Macmillan.

Khanh, V. (2012). Ho Chi Minh City tourism: Lose tourists due to language barriers. Journal of Business.Retrieved from http://vef.vn/201205-11-dn- lu-hanh-tp-hcm-mat-khach-vi-bat-dong-ngon-ngu-

Khotari, C.R. 2004. Research Methodology: Method and Techniques (2nd Revised Edition). New Delhi: New Age International Publisher.

Mountford, A.J. (1978) English for Specific Purposes. London : Longman. Rangkuti, F. 2004. SWOT Techniques Dissecting the Business Case.

Rangkuti, Freddy. 2003. Analisis Swot Teknik Membedah Kasus Bisnis. Jakarta: PT Gramedia Pustaka Utama.

Sugiyono, 2005. Qualitatif data analysis by Miles and huberman

Wright, C. (1992) ' The Benefits of ESP.' Cambridge Language Consultants. www.camalang.com/art00 1.htm Retrieved May 25th, 2004. 